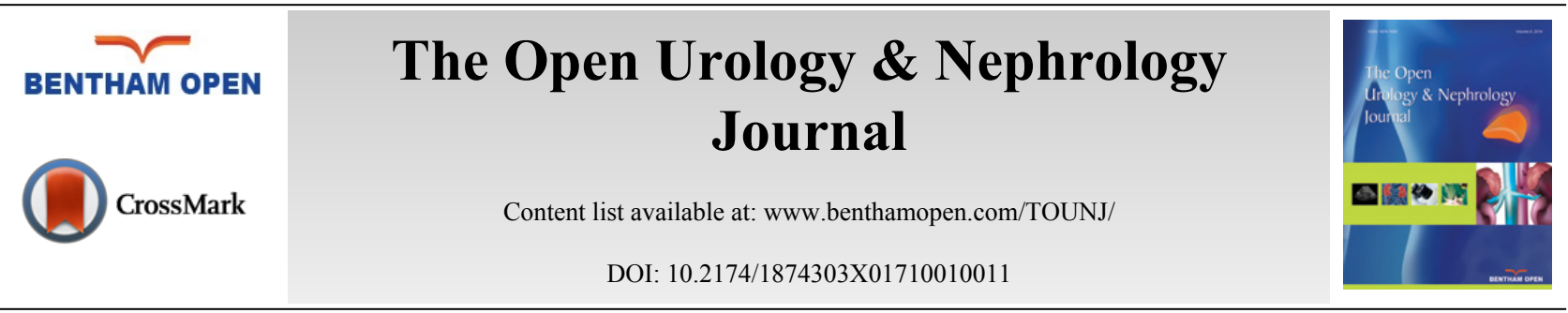

RESEARCH ARTICLE

\title{
Single Nucleotide Variants in A Family of Monozygotic Twins Discordant for the Phenotype Congenital Megaureter: A Genomic Analysis
}

\author{
Augusto C. Soares dos Santos Junior ${ }^{1,2,{ }^{*}}$, Luciana B. Rodrigues ${ }^{4}$, Raony G. Corrêa Do Carmo Lisboa \\ Cardenas $^{1}$, Patricia G.P. Couto ${ }^{1}$, Luiz A. Cunha de Marco ${ }^{1}$, Eduardo A. Oliveira ${ }^{3}$, Debora M. de \\ Miranda ${ }^{1}$ and Ana C. Simoes e Silva ${ }^{3}$ \\ ${ }^{I}$ National Institute of Science and Technology - Molecular Medicine [INCT-MM], Universidade Federal de Minas \\ Gerais [UFMG], Minas Gerais, Brazil \\ ${ }^{2}$ Nephrologist at Hospital das Clínicas, Universidade Federal de Minas Gerais [HC-UFMG], Empresa Brasileira de \\ Serviços Hospitalares [EBSERH], Minas Gerais, Brazil \\ ${ }^{3}$ Department of Pediatrics, Unit of Pediatric Nephrology, Interdisciplinary Laboratory of Medical Investigation, \\ Faculty of Medicine, UFMG, Minas Gerais, Brazil \\ ${ }^{4}$ Department of Basic Life Sciences, Universidade Federal de Juiz de Fora, Governador Valadares, Brazil
}

Received: November 07, 2016

Revised: March 01, 2017

Accepted: March 11, 2017

Abstract:

\section{Introduction:}

Congenital megaureter constitutes the second most frequent cause of hydronephrosis in children. There is still much debate on what extent environmental or genetic factors are involved in the pathogenesis of congenital megaureter.

\section{Objectives:}

This study aimed at investigating a pair of monozygotic twins discordant for the expression of bilateral congenital megaureter using the whole exome sequencing technique.

\section{Methods:}

Peripheral blood DNA was extracted and then sequenced using the whole exome technique from a pair of twins discordant for the presence of bilateral congenital refluxing unobstructed megaureter, his parents and a set of 11 non-related individuals with confirmed diagnosis of congenital megaureter. The DNA of the set of 11 non-related individuals was pooled in three groups. The monozygotic twins and their parents had DNA samples sequenced separately. Sanger validation was performed after data was filtered.

Results:

In the proband were identified 256 candidate genes, including TBX3, GATA6, DHH, LDB3, and HNF1, which are expressed in the urinary tract during the embryonic period. After Sanger validation, the SNVs found in the genes TBX3, GATA6, DHH and LDB3 were not confirmed in the proband. The SNV chr17:36104650 in the HNF1b gene was confirmed in the proband, his twin brother and the mother, however was not found in the pool of 11 non-related individuals with congenital megaureter.

\section{Conclusion:}

Due to the possible complex causative network of genetic variations and the challenges regarding the use of the whole exome

* Address correspondence to this author at the Hospital das Clínicas, Universidade Federal de Minas Gerais [UFMG], Av. Alfredo Balena, 110, Belo Horizonte, Minas Gerais, Brazil; Zip 30.130-100; Tel: +55 31-3409-9384; E-mail: acssjunior@hotmail.com 
sequencing technique we could not unequivocally associate the genetic variations identified in this study with the development of the congenital megaureter.

Keywords: CAKUT, Megaureter, Whole-exome sequencing, Twins.

\section{INTRODUCTION}

Congenital anomalies of the kidney and urinary tract [CAKUT] represent a broad range of disorders that result from abnormalities of the urinary collecting system, abnormal embryonic migration of the kidneys or abnormal renal parenchyma development $[1,2]$. Megaureter constitutes one of the phenotypes of CAKUT and represents a condition

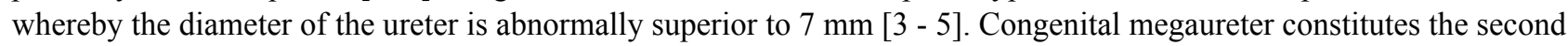
most frequent cause of hydronephrosis in children with an estimated incidence of 0.36 cases for every 1,000 newborns. Conceptually it can be classified according to the presence or the absence of vesicoureteral reflux and obstruction [6].

There is still much debate on what extent environmental, epigenetic or genetic factors are implicated in the pathogenesis of CAKUT. The current most accepted theory supports the influence of a complex interaction between environmental, epigenetic and genetic factors, suggesting that the pathogenesis of CAKUT is multifactorial [7]. However, uncertainty is especially true when the debate comes specifically to the factors involved in the development of congenital megaureter. Some authors have hypothesized that variations in specific regions of the genome could imbalance the mechanisms related to the expression of cytokines that modulate the ureter morphogenesis [8 - 10]. In other words, changes affecting single nucleotides could be a possible mechanism to trigger abnormal pathways, which would eventually signal to the development of the megaureter [11 - 13]. In this context, several genes have emerged as potential candidates [14]. Alterations with single nucleotides are detected by whole-exome sequencing [WES], a technique used to determine the DNA sequence for protein coding regions known as exons [14 - 22]. The exons represents only about $1.5 \%$ of the genome, however it is currently believed that $85 \%$ of all genetic diseases derive from modifications in this region of the genome [23, 24].

Taking all these factors together, the study of discordant monozygotic twins has become of special interest in the study of patients with congenital megaureter, since this approach offers the opportunity to control for potential confounders, including differences in genetic background or in utero environment [25 - 28]. Therefore, this study aimed to investigate a pair of monozygotic twins discordant for the expression of bilateral congenital megaureter and for the presence of genetic variants by using the WES technique. Validation with an external sample of non-related cases of megaureter was also used to further assess the possible association between gene and disease.

\section{PATIENTS AND METHODS}

\subsection{Patients and Clinical Assessment}

This study included twins discordant for the presence of bilateral congenital refluxing unobstructed megaureter, his parents and a set of 11 non-related individuals with confirmed diagnosis of congenital megaureter (see Fig. (1) and Table 1). Ultrasound [US] scan was performed in all cases after 28 weeks of gestation. Megaureter was considered to be present in case of an ureter diameter superior to $7 \mathrm{~mm}$ in fetal US [3,5]. Patients were followed up at the Pediatric Nephrology Unit of the Hospital das Clínicas - Universidade Federal de Minas Gerais [UFMG], Brazil and all of them underwent postnatal image and laboratory investigation according to a systematic protocol as detailed described elsewhere [29].

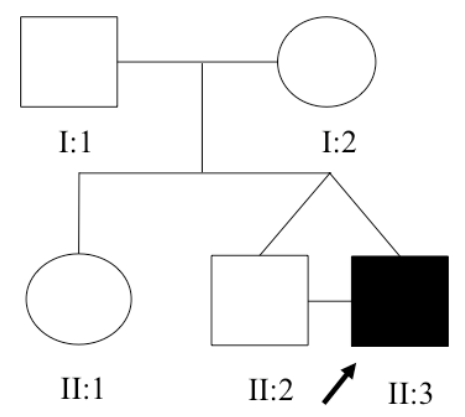

Fig. (1). Pedigree of the family under study. 
Table 1. Phenotypic characteristics for the non-related primary megaureter patients.

\begin{tabular}{|c|c|c|c|}
\hline & Date of birth & Gender & Phenotype \\
\hline $\mathbf{1 .}$ & $09 / 06 / 2001$ & Male & Congenital right nonrefluxing unobstructed megaureter \\
\hline $\mathbf{2 .}$ & $22 / 05 / 2002$ & Female & Congenital right nonrefluxing unobstructed megaureter \\
\hline $\mathbf{3 .}$ & $06 / 04 / 1992$ & Male & Congenital right nonrefluxing unobstructed megaureter \\
\hline $\mathbf{4 .}$ & $02 / 04 / 2005$ & Male & Congenital left nonrefluxing unobstructed megaureter \\
\hline $\mathbf{5 .}$ & $21 / 11 / 2006$ & Male & Congenital left nonrefluxing unobstructed megaureter \\
\hline $\mathbf{6 .}$ & $14 / 04 / 1989$ & Female & Congenital bilateral nonrefluxing unobstructed megaureter \\
\hline $\mathbf{7 .}$ & $01 / 12 / 2007$ & Female & Congenital bilateral nonrefluxing unobstructed megaureter \\
\hline $\mathbf{8 .}$ & $16 / 05 / 1999$ & Female & Congenital left nonrefluxing unobstructed megaureter \\
\hline $\mathbf{9 .}$ & $14 / 03 / 1999$ & Female & Congenital left nonrefluxing unobstructed megaureter \\
\hline $\mathbf{1 0 .}$ & $15 / 04 / 2004$ & Male & Congenital left nonrefluxing unobstructed megaureter \\
\hline $\mathbf{1 1 .}$ & $17 / 10 / 2007$ & Male & \\
\hline
\end{tabular}

The local Ethics Committee approved this study in accordance with the principles outlined in the Declaration of Helsinki. Informed consent was obtained from the parents or responsible for all participants. The study protocol did not interfere with any medical recommendation or prescription.

The family under study was constituted of 3 siblings (Fig. 1). The older sister refused to have blood samples collected and consequently she was not included in the genomic analysis. All family members, except the proband, had normal renal function and normal kidney and urinary tract anatomy. The twins, born in 22/08/2008 at $38 \pm 1$ weeks of gestation, were monozygotic, monochorionic and diamniotic. The first signs of CAKUT in the proband were seen during the US screening at $29 \pm 1$ weeks of gestation when his fetal biometry revealed left kidney ectasy and an increase bladder volume. In a spite of these prenatal US findings, the proband was not primarily referred for further investigations or treatment. A retrospective evaluation of pregnancy history did not identify exposure to known environmental risk factors for fetal anomalies. During his first month of life, in 19/09/2008, the proband developed urinary tract infection followed by sepsis and acute renal failure. He was then hospitalized in an intensive care unit and started peritoneal dialysis. Interruption of the dialysis sessions occurred after infection control and partial recovery of the renal function. During the hospital stay, a miccional urethrocystography revealed bilateral megaureter associated with grade V vesicoureteral reflux, as shown in (Fig. 2). In 13/10/2008, the proband underwent bilateral surgical reimplant of the ureters and was then referred to outpatient care at the Pediatric Nephrology Unit. At the time of recruitment, the two monozygotic twins were five years old and the proband exhibited CKD stage III.

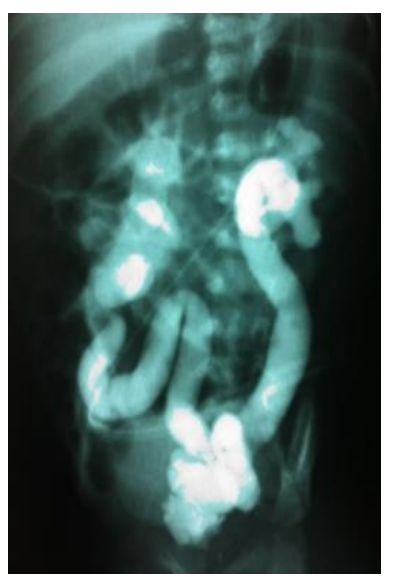

Fig. (2). Phenotype of the proband [miccional urethrocystography].

\subsection{DNA Extraction and Whole Exome Sequencing}

After the signature of the informed consent, all participants underwent an intravenous puncture to collect $15 \mathrm{ml}$ of peripheral blood samples. DNA was extracted from peripheral blood lymphocytes by the method described by Lahiri and Nurnberger [30]. All samples were checked for quality control and purity using a Nanodrop spectrophotometer [Thermo Scientific, Waltham, MA]. DNA samples were stored at $-20^{\circ} \mathrm{C}$ until usage. 
Peripheral blood DNA was extracted from the subjects under study and underwent whole exome capturing and sequencing using the Roche NimbleGen V2 chip [Madison, Wisconsin] or Nextera [San Diego, California] with the Illumina HiSeq2000 sequencing platform [San Diego, California]. The monozygotic twins and their parents had DNA samples sequenced separately. The DNA of the set of 11 non-related individuals with confirmed diagnosis of congenital megaureter was pooled in three groups. Array capture was used to isolate relevant human genes [Roche/NimblegenSeqCap EZ Human Exome Library v2.0]. These genes were sequenced on the Illumina HiSeq2000 platform [19].

\subsection{Variantion Calling and Annotation}

Raw sequence files were prepared using the Genome Analysis Tool Kit [GATK] for each of the sequenced samples. Each fastq file was aligned against the human hg19/GRCh37 reference genome. PCR duplicates were removed using Picard [http://picard.sourceforge.net/], reads around known and detected indels were realigned, and base quality was recalibrated using GATK. In order to call variants from the processed BAM files, a variant calling pipeline from GATK was applied. All generated VCF files were analyzed using Mendel MD software developed by the Clinical Genomic Laboratory of UFMG and available at http://mendel.medicina.ufmg.br [31].

\subsection{Filtering Data}

Previously described single nucleotide variants [SNVs], by November 2015, in the following databases were excluded: Project 1000 genomes [32], Exome Variant Server NHLBI GO Exome Sequencing Project [ESP] and dbSNP database [33].

To prioritize the high quality variants, SNVs fulfilling the following criteria were excluded: [i] variants within intergenic, intronic, and UTR regions; [ii] synonymous mutations; [iii] variants with phred quality score minor than 20; [iv] variants with conservation score [phyloP] inferior to 3 .

Sanger validation was performed after analysis of the literature for the identified genes regarding its known function and expression in kidney related structures during the embrionary period. The final set of selected variants was visually inspected using Integrative Genomics Viewer [IGV version 2.3.40] [34]. The prediction of amino acid substitution on the biological function of the protein [35] was evaluated using the PolyPhen2 [36].

\subsubsection{Validation of Data}

Sanger sequencing was utilized in the analysis to confirm SNVs in the selected genes. Amplification products of appropriate size were identified using polyacrylamide gel electrophoresis. Products were purified using the QIAquick PCR purification kit [QIAGEN, Milano, Italy] and then submitted to sequencing reaction using both forward and reverse primers with the ABI BigDye Terminator Cycle Sequencing Kit v3.1 on an ABI PRISM 3130 Genetic Analyzer [Applied Biosystems, Foster City, USA]. Each read was aligned to the reference sequence, and mutations were identified with the Sequencer software [GeneCodes, Ann Arbor, MI].

\section{RESULTS}

In the proband, 70.8 million reads were sequenced with a mean read length of 74 base pairs [bp]. The mapped bp mean error rate was $0.41 \%$, and the resultant mean base coverage was 71.8 times. A total of $95.5 \%$ of the sequenced bases were covered at least eight times by band reads. The observed number of SNVs, nonsynonymous mutations, read depth and read quality for each individual in this study and the pools are described in (Table 2).

Table 2. Whole exome reading parameters in the population studied.

\begin{tabular}{|c|c|c|c|c|}
\hline & SNVs & $\begin{array}{c}\text { Non } \\
\text { synonymous } \\
\text { mutations }\end{array}$ & Read depth* & Read quality* \\
\hline Proband & 40,123 & 15,028 & $61.23[1 / 200]$ & $963.4[10.2 / 7,844.7]$ \\
\hline Proband father & 43,104 & 15,968 & $65.2[1 / 200]$ & $1,036.8[10.2 / 7,990.7]$ \\
\hline Proband mother & 38,141 & 14,032 & $63.2[1 / 200]$ & $1,035.6[10.2 / 7,836.7]$ \\
\hline Proband brother & 41,008 & 14,961 & $73.2[1 / 200]$ & $1,138.7[10.2 / 7,679.7]$ \\
\hline
\end{tabular}


(Table 2) contd.....

\begin{tabular}{|l|c|c|c|c|}
\hline & SNVs & $\begin{array}{c}\text { Non } \\
\text { synonymous } \\
\text { mutations }\end{array}$ & Read depth* & Read quality* \\
\hline Megaureter pool 1 & 42,983 & 15,606 & $71.7[1 / 200]$ & $1,142.4[10.2 / 7,838.7]$ \\
Megaureter pool 2 & 53,862 & 19,662 & $74.3[1 / 200]$ & $752.0[10.2 / 7,959.7]$ \\
Megaureter pool 3 & 54,267 & 19,871 & $78.8[1 / 200]$ & $724.2[10.2 / 7,642.7]$ \\
\hline
\end{tabular}

* Mean [range].

The proband had 40,123 SNVs identified. The proband and his twin shared 35,990 [88.96\%] SNVs. From these, 35,695 [99.2\%] SNVs resulted in common genotypes. Similarly, the proband shared 29,516 [59\%] and 27,114 [52.58\%] of SNVs and 5,842 [20\%] and 6,019 [22\%] common genotypes, with his father and mother, respectively.

After data filtering, we found in the proband 256 candidate genes with variants, (Table 3). Among these, we identify genes expressed in urinary tract during embrionary period including TBX3, GATA6, DHH, LDB3, and HNF1b. The variants in these genes were selected for Sanger validation, (Table 4).

Table 3. Candidate variants in the proband after data filtering.

\begin{tabular}{|c|c|}
\hline & Frequency \\
\hline Total number of SNVs in the proband & 40,123 \\
\hline Number of previously described SNVs * [excluded] & $\mathbf{3 6 , 1 6 5}$ \\
\hline SNVs identified as coding silent, intergenic, intronic, UTR and synonymous mutations, quality score $<20$, PhyloP score $<3$ & $\mathbf{3 , 7 0 2}$ \\
\hline [excluded] & $\mathbf{2 5 6}$ \\
\hline
\end{tabular}

*Project 1000 genomes [32], Exome Variant Server NHLBI GO Exome Sequencing Project [ESP], dbSNV database [33]. November 2015.

Table 4. SNVs selected for Sanger validation.

\begin{tabular}{|c|c|c|c|c|c|c|}
\hline Gene & Chr & Chr position [hg19] & Códon change & Zygosity & AA change & PolyPhen-2 [36] \\
\hline TBX3 & 12 & 115110015 & $\mathrm{G}>\mathrm{T}$ & Heterozygous & $\mathrm{S} 621 \mathrm{R}$ & 0,534 \\
\hline DHH & 12 & 49483730 & $\mathrm{G}>\mathrm{A}$ & Heterozygous & $\mathrm{A} 368 \mathrm{~V}$ & 0,898 \\
\hline GATA6 & 18 & 19751573 & $\mathrm{C}>\mathrm{A}$ & Heterozygous & $\mathrm{S} 156 \mathrm{R}$ & 0,761 \\
\hline LDB3 & 10 & 88476146 & $\mathrm{~T}>\mathrm{C}$ & Heterozygous & $\mathrm{S} 437 \mathrm{P}$ & 0,969 \\
\hline HNF1b & 17 & 36070591 & $\mathrm{~T}>\mathrm{G}$ & Heterozygous & $\mathrm{G} 76 \mathrm{C}$ & 0,966 \\
\hline
\end{tabular}

The SNVs found in the genes TBX3, GATA6, DHH and LDB3 were not confirmed in the proband. The heterozygote variant in the HNF1b gene was confirmed in the proband, his twin brother and the mother, as shown in (Table 5). The SNV chr17:36104650 in the HNF1b gene was not found in the pool of 11 non-related individuals with congenital megaureter.

Table 5. Summary of sequencing results.

\begin{tabular}{|c|c|c|c|c|c|}
\hline Subjects & $\begin{array}{c}\text { TBX3 } \\
\text { S621R } \\
\text { agC/agA }\end{array}$ & $\begin{array}{c}\text { GATA6 } \\
\text { S156R } \\
\text { agC/agA }\end{array}$ & $\begin{array}{c}\text { DHH } \\
\text { A368V } \\
\text { gCg/gTg }\end{array}$ & $\begin{array}{c}\text { LDB3 } \\
\text { S437P } \\
\text { Tcc/Ccc }\end{array}$ & $\begin{array}{c}\text { HNF1B } \\
\text { G76C } \\
\text { Gge/Tgc }\end{array}$ \\
\hline Proband & $\mathrm{C} / \mathrm{C}$ & $\mathrm{C} / \mathrm{C}$ & $\mathrm{C} / \mathrm{C}$ & $\mathrm{T} / \mathrm{T}$ & $\mathrm{G} / \mathrm{T}$ \\
\hline Proband Father & $\mathrm{C} / \mathrm{C}$ & $\mathrm{C} / \mathrm{C}$ & $\mathrm{C} / \mathrm{C}$ & $\mathrm{T} / \mathrm{T}$ & $\mathrm{G} / \mathrm{G}$ \\
\hline Proband Mother & $\mathrm{C} / \mathrm{C}$ & $\mathrm{C} / \mathrm{C}$ & $\mathrm{C} / \mathrm{C}$ & $\mathrm{T} / \mathrm{T}$ & $\mathrm{G} / \mathrm{T}$ \\
\hline Proband brother & $\mathrm{C} / \mathrm{C}$ & $\mathrm{C} / \mathrm{C}$ & $\mathrm{C} / \mathrm{C}$ & $\mathrm{T} / \mathrm{T}$ & $\mathrm{G} / \mathrm{T}$ \\
\hline
\end{tabular}

\section{DISCUSSION}

Studies with monozygotic twins can be decisive in the elucidation of the molecular mechanisms involved in the development of congenital diseases in humans, especially because, in contrast to other individuals, monozygotic twins share similar prenatal environments as well as a common genetic background [13]. In this study, we identified 40,123 SNVs in the proband. The overall read quality and read depth obtained with the WES was considered satisfactory. Comparison between the proband and his brother yield $99.2 \%$ of genotype similarity in common SNVs regions, confirming their condition of monozygotic twins. 
In humans, heterozygous mutations of the $H N F 1 b$ gene may result in several kidney abnormalities, once it is directly involved in nephrogenesis [37, 38]. Currently several phenotypes are associated with variations in the $H N F 1 b$ gene including the formation of cysts, oligomeganephronia, renal agenesis, renal hypoplasia, and familial juvenile hyperuricemic nephropathy [39 - 44]. Our results indicated the presence of a heterozygote SNV in the HNF1b gene, position chr17:36104650 [Ggc/Tgc], in the proband, his twin brother and mother. This SNV resulted in a high PolyPhen-2 [36] score suggesting that this variant may lead to a damaging change in protein structure. Unfortunately, this result was not replicated in a pool of 11 non-related individuals with congenital megaureter. Therefore, our findings, despite suggestive, did not allow us to confirm a role of the gene $H N F 1 b$ in the pathogenesis of the megaureter.

Other authors have suggested that the HNF1b gene cooperates with other genes as Pax 8 and Lim 1, during early organogenesis, to the construction of a healthy functional kidney [37, 38, 45, 46]. The hypothesis of a complex regulatory mechanism involving the participation of more than one gene is corroborated by the observation that the SNV at the HNF1b gene was detected in heterozygosis in two healthy individuals, the mother and the brother of the proband. Other studies involving patients with CAKUT have also failed in isolating genetic monogenetic determinants [7, 13, 47 - 49]. Recently, Jin et al. [47] published a study investigating monozygotic twins discordant for congenital renal agenesis from a set of blood samples using high-throughput exome-capture sequencing to detect single-nucleotide polymorphisms [SNPs], copy number variations [CNVs], insertions and deletions [indels] and differentially methylated regions [DMRs]. In this study, no discordant SNPs, CNVs, or indels were confirmed. To explain these results, some studies have suggested that, despite the apparent environmental similarities shared by these individuals, the intrauterine milieu is not necessarily equal for both twins [50]. Monozygotic twins could have differences due to the number of cells allocated to each twin, the timing of the twinning process, the vascular distribution from the placenta and epigenetic factors [12]. This can be especially true in monochorionic twins, the term used to refer to twins sharing the same placenta [51].

Our search for a genetic trigger for the development of megaureter was marked for several methodologic limitations. In this study, investigation of somatic mosaicism or RNAs expression in the affected tissue was impossible, since the samples obtained during the bilateral surgical re-implantation of the ureters in the proband were not available. In addition, despite being a promising tool, the WES method is still under development. For this reason, WES still poses challenges regarding the establishement of a standard method for data analysis and for the interpretation of the results [52]. Consequently, the combination of other bioinformatics techniques [53, 54], including data from prior GWAS studies, may still be needed for identifying causative mutations.

In conclusion, our study was not able to prove the association of HNF1b gene with the pathogenesis of the congenital megaureter by using WES technique and Sanger validation. In spite of that, we believe that the study of genetic differences within discordant monozygotic twins may help to decipher the complex network beyond genetic variations in the development of congenital megaureter.

\section{CONFLICT OF INTEREST}

The authors confirm that this article content has no conflict of interest.

\section{ACKNOWLEDGEMENTS}

Declared none.

\section{REFERENCES}

[1] Fletcher J, McDonald S, Alexander SI. Prevalence of genetic renal disease in children. Pediatr Nephrol 2013; $28(2)$ : $251-6$. [http://dx.doi.org/10.1007/s00467-012-2306-6] [PMID: 23052649]

[2] Queisser-Luft A, Stolz G, Wiesel A, Schlaefer K, Spranger J. Malformations in newborn: Results based on 30,940 infants and fetuses from the Mainz congenital birth defect monitoring system [1990-1998]. Arch Gynecol Obstet 2002; 266(3): 163-7. [PMID: 12197558]

[3] Cussen LJ. Dimensions of the normal ureter in infancy and childhood. Invest Urol 1967; 5(2): 164-78. [PMID: 6052953]

[4] Hellström M, Hjälmås K, Jacobsson B, Jodal U, Odén A. Normal ureteral diameter in infancy and childhood. Acta Radiol Diagn (Stockh) 1985; 26(4): 433-9.

[PMID: 4050524] 
[5] Farrugia M-K, Hitchcock R, Radford A, Burki T, Robb A, Murphy F. British association of paediatric urologists consensus statement on the management of the primary obstructive megaureter. J Pediatr Urol 2014; 10(1): 26-33. [http://dx.doi.org/10.1016/j.jpurol.2013.09.018] [PMID: 24206785]

[6] Stoll C, Alembik Y, Roth MP, Dott B, Sauvage P. Risk factors in internal urinary system malformations. Pediatr Nephrol 1990; 4(4): 319-23. [http://dx.doi.org/10.1007/BF00862508] [PMID: 2206898]

[7] Bulum B, Ozçakar ZB, Ustüner E, et al. High frequency of kidney and urinary tract anomalies in asymptomatic first-degree relatives of patients with CAKUT. Pediatr Nephrol 2013; 28(11): 2143-7. [http://dx.doi.org/10.1007/s00467-013-2530-8] [PMID: 23812353]

[8] dos Santos Junior AC, de Miranda DM, Simões e Silva AC. Congenital anomalies of the kidney and urinary tract: An embryogenetic review. Birth Defects Res Part C Embryo Today 2014; 102(4): 374-81. [http://dx.doi.org/10.1002/bdrc.21084] [PMID: 25420794]

[9] Miyazaki Y, Ichikawa I. Ontogeny of congenital anomalies of the kidney and urinary tract, CAKUT. Pediatr Int 2003; 45(5): 598-604. [http://dx.doi.org/10.1046/j.1442-200X.2003.01777.x] [PMID: 14521544]

[10] Nicotina PA, Romeo C, Arena F, Romeo G. Segmental up-regulation of transforming growth factor-beta in the pathogenesis of primary megaureter. An immunocytochemical study. Br J Urol 1997; 80(6): 946-9. [http://dx.doi.org/10.1046/j.1464-410X.1997.00486.x] [PMID: 9439416]

[11] Bartels E, Draaken M, Kazmierczak B, et al. De novo partial trisomy 18p and partial monosomy 18q in a patient with anorectal malformation. Cytogenet Genome Res 2011; 134(3): 243-8 [http://dx.doi.org/10.1159/000328833] [PMID: 21709416]

[12] Machin GA. Some causes of genotypic and phenotypic discordance in monozygotic twin pairs. Am J Med Genet 1996; 61(3): 216-28. [http://dx.doi.org/10.1002/(SICI)1096-8628(19960122)61:3<216::AID-AJMG5>3.0.CO;2-S] [PMID: 8741866]

[13] Baudisch F, Draaken M, Bartels E, et al. CNV analysis in monozygotic twin pairs discordant for urorectal malformations. Twin Res Hum Genet 2013; 16(4): 802-7. [http://dx.doi.org/10.1017/thg.2013.29] [PMID: 23659922]

[14] Bekheirnia MR, Bekheirnia N, Bainbridge MN, et al. Whole-exome sequencing in the molecular diagnosis of individuals with congenital anomalies of the kidney and urinary tract and identification of a new causative gene. Genet Med 2016. [Epub ahead of print] [http://dx.doi.org/10.1038/gim.2016.131] [PMID: 27657687]

[15] Solomon BD, Hadley DW, Pineda-Alvarez DE, et al. Incidental medical information in whole-exome sequencing. Pediatrics 2013; 129(6): e1605-11. [http://dx.doi.org/10.1542/peds.2011-0080] [PMID: 22585771]

[16] Yang Y, Muzny DM, Reid JG, et al. Clinical whole-exome sequencing for the diagnosis of mendelian disorders. N Engl J Med 2013; 369(16): $1502-11$. [http://dx.doi.org/10.1056/NEJMoa1306555] [PMID: 24088041]

[17] Bamshad MJ, Ng SB, Bigham AW, et al. Exome sequencing as a tool for Mendelian disease gene discovery. Nat Rev Genet 2011; 12(11): 745-55. [Internet]. [http://dx.doi.org/10.1038/nrg3031] [PMID: 21946919]

[18] Linderman MD, Brandt T, Edelmann L, et al. Analytical validation of whole exome and whole genome sequencing for clinical applications. BMC Med Genomics 2014; 7: 20. [Internet]. [http://dx.doi.org/10.1186/1755-8794-7-20] [PMID: 24758382]

[19] Bao R, Huang L, Andrade J, et al. Review of current methods, applications, and data management for the bioinformatics analysis of whole exome sequencing. Cancer Inform 2014; 13(Suppl. 2): 67-82. [PMID: 25288881]

[20] Pereira PC, Melo FM, De Marco LA, Oliveira EA, Miranda DM, Simões e Silva AC. Whole-exome sequencing as a diagnostic tool for distal renal tubular acidosis. J Pediatr (Rio J) 2015; 91(6): 583-9. [Rio J]. [http://dx.doi.org/10.1016/j.jped.2015.02.002] [PMID: 26208211]

[21] Solomon BD, Hadley DW, Pineda-Alvarez DE, et al. Incidental medical information in whole-exome sequencing. Pediatrics 2012; 129(6): e1605-11. [http://dx.doi.org/10.1542/peds.2011-0080] [PMID: 22585771]

[22] Rabbani B, Tekin M, Mahdieh N. The promise of whole-exome sequencing in medical genetics. J Hum Genet 2014; 59(1): 5-15. [http://dx.doi.org/10.1038/jhg.2013.114] [PMID: 24196381]

[23] Majewski J, Schwartzentruber J, Lalonde E, Montpetit A, Jabado N. What can exome sequencing do for you? J Med Genet 2011; 48(9): 580-9. [http://dx.doi.org/10.1136/jmedgenet-2011-100223] [PMID: 21730106]

[24] Botstein D, Risch N. Discovering genotypes underlying human phenotypes: past successes for mendelian disease, future approaches for complex disease. Nat Genet 2003; 33(3s)(Suppl.): 228-37. [http://dx.doi.org/10.1038/ng1090] [PMID: 12610532] 
[25] Nicolaou N, Renkema KY, Bongers EM, Giles RH, Knoers NV. Genetic, environmental, and epigenetic factors involved in CAKUT. Nat Rev Nephrol 2015; 11(12): 720-31. [Internet]. [http://dx.doi.org/10.1038/nrneph.2015.140] [PMID: 26281895]

[26] Yosypiv I V. Congenital anomalies of the kidney and urinary tract: a genetic disorder? Int J Nephrol 2012; 2012: 909083. [http://dx.doi.org/10.1155/2012/909083] [PMID: 22685656]

[27] Mantan M, Sethi GR. Congenital anomalies of kidney and urinary tract in siblings: An uncommon condition. Indian J Nephrol 2013; 23(3): 217-9. [http://dx.doi.org/10.4103/0971-4065.111858] [PMID: 23814423]

[28] Tan Q, Christiansen L, von Bornemann Hjelmborg J, Christensen K. Twin methodology in epigenetic studies. J Exp Biol 2015; 218(Pt 1): $134-9$.

[29] Quirino IG, Diniz JS, Bouzada MC, et al. Clinical course of 822 children with prenatally detected nephrouropathies. Clin J Am Soc Nephrol 2012; 7(3): 444-51. [http://dx.doi.org/10.2215/CJN.03400411] [PMID: 22266574]

[30] Lahiri DK, Nurnberger JI Jr. A rapid non-enzymatic method for the preparation of HMW DNA from blood for RFLP studies. Nucleic Acids Res 1991; 19(19): 5444

[http://dx.doi.org/10.1093/nar/19.19.5444] [PMID: 1681511]

[31] Guimarães Corrêa Do Carmo Lisboa Cardenas R, Duarte Linhares N, Junho Pena SD. Mendel, MD: A user-friendly online program for clinical exome analysis. BMC Bioinformatics 2015; 16(Suppl. 8): A2. [Internet]. [http://dx.doi.org/10.1186/1471-2105-16-S8-A2]

[32] Abecasis GR, Altshuler D, Auton A, et al. A map of human genome variation from population-scale sequencing. Nature 2010; 467(7319): 1061-73.

[http://dx.doi.org/10.1038/nature09534] [PMID: 20981092]

[33] Wheeler DL, Barrett T, Benson DA, et al. Database resources of the National Center for Biotechnology Information. Nucleic Acids Res 2007; 35(Database issue): D5-12.

[34] Robinson JT, Thorvaldsdóttir H, Winckler W, et al. Integrative genomics viewer. Nat Biotechnol 2011; 29(1): 24-6. [http://dx.doi.org/10.1038/nbt.1754] [PMID: 21221095]

[35] Rudd MF, Williams RD, Webb EL, Schmidt S, Sellick GS, Houlston RS. The predicted impact of coding single nucleotide polymorphisms database. Cancer Epidemiol Biomarkers Prev 2005; 14(11 Pt 1): 2598-604. [http://dx.doi.org/10.1158/1055-9965.EPI-05-0469] [PMID: 16284384]

[36] Adzhubei I, Jordan DM, Sunyaev SR. Predicting functional effect of human missense mutations using PolyPhen-2. Curr Protoc Hum Genet 2013; Chapter 7:Unit7: 20. [http://dx.doi.org/10.1002/0471142905.hg0720s76] [PMID: 23315928]

[37] Nakayama M, Nozu K, Goto Y, et al. HNF1B alterations associated with congenital anomalies of the kidney and urinary tract. Pediatr Nephrol 2010; 25(6): 1073-9. [Internet]. [http://dx.doi.org/10.1007/s00467-010-1454-9] [PMID: 20155289]

[38] Paces-Fessy M, Fabre M, Lesaulnier C, Cereghini S. Hnflb and Pax2 cooperate to control different pathways in kidney and ureter morphogenesis. Hum Mol Genet 2012; 21(14): 3143-55. [http://dx.doi.org/10.1093/hmg/dds141] [PMID: 22511595]

[39] Madariaga L, Morinière V, Jeanpierre C, et al. Severe prenatal renal anomalies associated with mutations in HNF1B or PAX2 genes. Clin J Am Soc Nephrol 2013; 8(7): 1179-87. [http://dx.doi.org/10.2215/CJN.10221012] [PMID: 23539225]

[40] Thomas R, Sanna-Cherchi S, Warady BA, Furth SL, Kaskel FJ, Gharavi AG. HNF1B and PAX2 mutations are a common cause of renal hypodysplasia in the CKiD cohort. Pediatr Nephrol 2011; 26(6): 897-903. [http://dx.doi.org/10.1007/s00467-011-1826-9] [PMID: 21380624]

[41] Verbitsky M, Sanna-cherchi S, Fasel DA, et al. Genomic imbalances in pediatric patients with chronic kidney disease. J Clin Invest 2015; 125(5): 2171-8.

[http://dx.doi.org/10.1172/JCI80877] [PMID: 25893603]

[42] Heidet L, Decramer S, Pawtowski A, et al. Spectrum of HNF1B mutations in a large cohort of patients who harbor renal diseases. Clin J Am Soc Nephrol 2010; 5(6): 1079-90. [http://dx.doi.org/10.2215/CJN.06810909] [PMID: 20378641]

[43] Clissold RL, Hamilton AJ, Hattersley AT, Ellard S, Bingham C. HNF1B-associated renal and extra-renal disease-an expanding clinical spectrum. Nat Rev Nephrol 2014; 11(2): 102-2. [http://dx.doi.org/10.1038/nrneph.2014.232] [PMID: 25536396]

[44] Alvelos MI, Rodrigues M, Lobo L, et al. A novel mutation of the HNF1B gene associated with hypoplastic glomerulocystic kidney disease and neonatal renal failure: A case report and mutation update. Medicine (Baltimore) 2015; 94(7): e469. [http://dx.doi.org/10.1097/MD.0000000000000469] [PMID: 25700310] 
[45] Wu G, Bohn S, Ryffel GU. The HNF1beta transcription factor has several domains involved in nephrogenesis and partially rescues Pax8/lim1-induced kidney malformations. Eur J Biochem 2004; 271(18): 3715-28. [http://dx.doi.org/10.1111/j.1432-1033.2004.04312.x] [PMID: 15355349]

[46] Dudziak K, Mottalebi N, Senkel S, et al. Transcription factor HNF1beta and novel partners affect nephrogenesis. Kidney Int 2008; 74(2): 210-7. [http://dx.doi.org/10.1038/ki.2008.149] [PMID: 18418350]

[47] Jin M, Zhu S, Hu P, et al. Genomic and epigenomic analyses of monozygotic twins discordant for congenital renal agenesis. Am J Kidney Dis 2014; 64(1): 119-22. [http://dx.doi.org/10.1053/j.ajkd.2014.01.423] [PMID: 24583054]

[48] Gibson J, Gilbert RD, Bunyan DJ, Angus EM, Fowler DJ, Ennis S. Exome analysis resolves differential diagnosis of familial kidney disease and uncovers a potential confounding variant. Genet Res 2013; 95(6): 165-73. [Camb]. [http://dx.doi.org/10.1017/S0016672313000220] [PMID: 24472419]

[49] Zwijnenburg PJ, Meijers-Heijboer H, Boomsma DI. Identical but not the same: The value of discordant monozygotic twins in genetic research. Am J Med Genet B Neuropsychiatr Genet 2010; 153B(6): 1134-49. [PMID: 20468073]

[50] Ollikainen M, Smith KR, Joo EJ, et al. DNA methylation analysis of multiple tissues from newborn twins reveals both genetic and intrauterine components to variation in the human neonatal epigenome. Hum Mol Genet 2010; 19(21): 4176-88. [http://dx.doi.org/10.1093/hmg/ddq336] [PMID: 20699328]

[51] Gordon L, Joo JE, Powell JE, et al. Neonatal DNA methylation profile in human twins is specified by a complex interplay between intrauterine environmental and genetic factors, subject to tissue-specific influence. Genome Res 2012; 22(8): 1395-406. [http://dx.doi.org/10.1101/gr.136598.111] [PMID: 22800725]

[52] Bertier G, Hétu M, Joly Y. Unsolved challenges of clinical whole-exome sequencing: A systematic literature review of end-users views. BMC Med Genomics 2016; 9(1): 52. [Internet].

[http://dx.doi.org/10.1186/s12920-016-0213-6] [PMID: 27514372]

[53] Alemán A, Garcia-Garcia F, Salavert F, Medina I, Dopazo J. A web-based interactive framework to assist in the prioritization of disease candidate genes in whole-exome sequencing studies. Nucleic Acids Res 2014; 42(Web Server issue): W88-93. [http://dx.doi.org/10.1093/nar/gku407] [PMID: 24803668]

[54] Wu J, Li Y, Jiang R. Integrating multiple genomic data to predict disease-causing nonsynonymous single nucleotide variants in exome sequencing studies. PLoS Genet 2014; 10(3): e1004237. [http://dx.doi.org/10.1371/journal.pgen.1004237] [PMID: 24651380]

(C) 2017 Soares dos Santos Junior et al.

This is an open access article distributed under the terms of the Creative Commons Attribution 4.0 International Public License (CC-BY 4.0), a copy of which is available at: https://creativecommons.org/licenses/by/4.0/legalcode. This license permits unrestricted use, distribution, and reproduction in any medium, provided the original author and source are credited. 